\title{
Editorial
}

\section{Meu pseudônimo e eu}

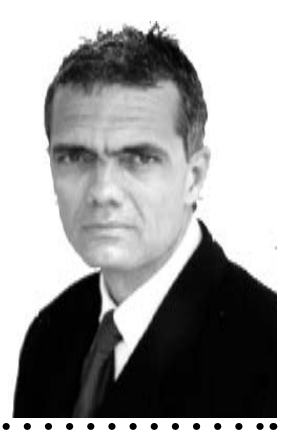

Marco Antonio Guimarães da Silva

Como pesquisadores e professores de curso de pós-graduação Stricto Sensu (mestrado e doutorado) também somos obrigado a fazer o nosso dever de casa, um deles é escrever e publicar artigos científicos. Para a grande maioria dos pesquisadores o ato de escrever artigos científicos representa a primeira experiência como artífice das palavras, mas possui, contudo, uma característica muito peculiar: somos, enquanto escritores pesquisadores narradores que utilizamos um material linguístico que fala para um leitor invisível, um leitor impessoalizado. Não precisamos, nesse caso, fundamentar os personagens, simplesmente porque eles não existem. $\mathrm{O}$ que escrevemos, como autores científicos, quando chega aos nossos leitores, não se transforma em imagens que os remeterão a um ou mais universos, universos estes que mexerão com as suas emoçōes, os seus sentimentos, os seu medos ou com tudo aquilo que a sua mente seja capaz de elaborar. Talvez um artigo, que revelasse a descoberta de um meteoro em rota de colisão a terra, ou uma pesquisa, que identificasse a mutação de um vírus cuja letalidade nos mandaria para o além, fugisse ao que acabei de dizer.

Como bom geminiano que dizem que sou, achei que era hora de mudar, de fazer incursões mais ousadas e aventurar-me no campo da ficcionalização. A mudança não foi repentina, porque a maior parte dos editorais que escrevi, nesses últimos doze anos, para Fisioterapia Brasil foram atravessados por uma visão interessada na sociedade, fugindo da estrutura de artigos científicos, e serviram como uma ponte que me levou ao mudo ficcional. O meu primeiro romance De escritores, fantasmas e mortos (Ed. Livre Expressáo), escrito sob o pseudônimo de Paul Lodd, trata da flânerie e da violência das urbes atuais, onde a multidão já não é mais um refúgio para o flâneur dos chamados tempos pós-modernos e onde os impasses se multiplicam. Trata da figura do baladeur, que perambula por múltiplos espaços, geográficos e virtuais, como um observador anônimo em constante deslocamento. A literatura, com seus escritores, personagens e projetos, se transforma em um grande espaço, onde sonho e realidade duelam entre si. Um de meus desejos, nessa obra, é que, pelas "ruas" do texto, os leitores possam ser conduzidos a reconstruir o olhar hesitante do flâneur, dividido entre o horror e o encantamento, entre o pesadelo e o sonho.

Se me perguntarem, mas porque o pseudônimo? Eu darei a mesma resposta que dei para um crítico literário norte americano especialista em literatura portuguesa, o professor Russell Hamilton, da Vanderbilt University e emérito da Yale (os comentários dele e de outros críticos podem ser vistos em "Bloco de Notas" do site: www.paul-lodd.fr): não sei, mas conselhos para que eu abandonasse a idéia do pseudônimo não me faltaram. Meus familiares e amigos praticamente me suplicaram: assine o livro com o teu próprio nome. Entretanto, não foi pelo meu nome que adotei o pseudônimo; enfim, ele não é tão comum e ordinário. Eu mesmo já me perguntei se estaria com vergonha dele. Mas, depois pensei: afinal não fui batizado como Dezêncio Feverêncio de Oitenta e Cinco ou Fridundino Eulâmpio. Sei que esses nomes existem, e os seus donos, tenho a certeza, se um dia escrevessem um livro, não usariam um pseudônimo. Não envergonhariam os seus pais ou seja lá quem quer que lhes tenha dado essas barbaridades alcunhativas. Portanto, a vergonha do nome em si não se aplicava ao meu caso. Seja lá como for, Inês é morta. Talvez, no segundo livro, já a caminho - Meu pseudônimo e eu -, eu assine o livro com o meu próprio nome.

Ass. Paul Lodd, Marco Antonio ou.....? 